\title{
INFORMATION SHEET/CONSENT FORM
}

\section{What we are doing}

As part of the University of Exeter's Effective Learning Analytics project, we are collecting data from students about their engagement with different resources and facilities at the University of Exeter. We will use the data provided by students in this research alongside digital data available about students' usage patterns to develop a greater understanding of how students' behaviour is associated with achievement and retention.

\section{What we are asking you to do}

If you agree to take part, you will be asked to complete a short survey about your behaviour each week in Term $2-11$ surveys in total. You will be emailed a link to the survey each week. The questions ask you about your use of different resources/facilities available to students each week.

You will also be asked to give consent for us to match the responses you give us to our questions with data recorded by the University of Exeter, such as your grades. For example, you will be asked about how often you have used ELE and then we would match this with your usage recorded by the ELE system.

Each weekly survey should only take about 5 minutes to complete. The first survey should take about 15 minutes to complete as it includes questions that we'll only ask you once.

\section{What happens to the information that you give us}

You do not have to take part in the survey if you don't want to. But by completing it, you will help us to better understand the factors that are associated with student performance.

Any information that you give us will be treated in strict confidence. Only the researchers will know that you have completed the questionnaire. Any personally identifying information will be removed from the datasets before we conduct our analyses: you will not be identified by anything you say.

\section{What are the benefits for you?}

In addition to helping us advance knowledge in this field, each week participating students will be entered into a prize draw to win one of $10 £ 20$ Amazon vouchers. In addition, students who complete $\mathbf{8}$ or more surveys will be entered into a final prize draw to win one of $\mathbf{1 0} \mathbf{f 5 0}$ Amazon vouchers.

\section{Ethical approval}

This research has been approved by the Psychology Ethics Committee in line with the guidelines of the British Psychological Society.

\section{Right to withdraw}

If you do not wish to answer a particular question on the survey, you do not have to. Any information that you give us is valuable. If you change your mind about participating at any time over the course of Term 2, you can do so by contacting the Project Contact person below.

\section{Project contact}




\section{Consent Form}

To sign up to participate in this research, please read through the statements below and continue with the study if you agree with each statement.

1. I have had the opportunity to consider the information about this study.

2. I understand that my participation in this study is voluntary and that I can withdraw from the study at any time.

3. I understand that by agreeing to participate, I give consent for my survey responses to be matched, based on my student number, with other data held by the University of Exeter about me.

4. I understand that my data will be confidential and anonymised prior to analysis by the research team.

5. I know how to contact the research team if I need to. 


\section{QUESTIONS TO BE ASKED EACH WEEK}

First, we'd like to ask you some questions about your engagement with a number of resources, facilities, and activities at the University of Exeter. Please indicate on how many days over the past week you accessed each resource.

Over the last week, on how many days did you:

Work/study with friends

Interact with a lecturer

Use iExeter

Use ELE

Attend a scheduled teaching session (e.g., lecture)

Access library resources

Use the Sports Park (e.g., gym, fitness classes)

Access the Career Zone

Use Guild facilities (e.g., Voice, advice services)

Use the retail facilities on campus (e.g., Marketplace)

Use non-university social media platforms (e.g., Facebook, Twitter) for learning

Use the internet for learning (e.g., to find papers, tutorials etc)

Access past exam papers

Participate in clubs and societies

\begin{tabular}{|l|l|l|l|l|l|l|l|}
\hline $0 / 7$ days & $1 / 7$ days & $2 / 7$ days & $3 / 7$ days & $4 / 7$ days & $5 / 7$ days & $6 / 7$ days & $7 / 7$ days \\
\hline
\end{tabular}

Now, we'd like to ask you about how you felt about your studies over the last week.

Over the last week:

How engaged were you with your studies?

How satisfied were you with the quality of your course?

How much effort did you put into your studies?

How much did you feel part of a community of staff and students?

How happy did you feel about your life in general?

How well do you feel you are doing in your course?

\begin{tabular}{|l|l|l|l|l|}
\hline 1 & 2 & 3 & 4 & 5 \\
\hline Not at all & & & & Very much \\
\hline
\end{tabular}

Did you get a result back this week?

Yes/no

If yes, how satisfied were you with the mark you received?

\begin{tabular}{|l|l|l|l|l|}
\hline 1 & 2 & 3 & 4 & 5 \\
\hline Not at all & & & & Very much \\
\hline
\end{tabular}


Did you have an assessment due this week?

Yes/no

If yes, how much effort did you put into the assessment?

\begin{tabular}{|l|l|l|l|l|}
\hline 1 & 2 & 3 & 4 & 5 \\
\hline Not very much & & & & A lot \\
\hline
\end{tabular}




\section{ADDITIONAL QUESTIONS FOR TIME 1}

\section{STUDENT ENGAGEMENT}

In this next section, we're interested in how you feel about your learning experience at university. Please answer by indicating your level of agreement with each statement. [1 strongly disagree, to 5 strongly agree]

[behavioural engagement]

I try hard to do well at university

In my modules, I work as hard as I can

When I'm in class, I participate in class discussions

When I'm in class, I just act like I'm working

In my modules, I do just enough to get by

If I have trouble understanding something, I go over it again until I understand it

[cognitive engagement]

When I study, I try to understand the material better by relating it to things I already know

When I study, I figure out how the information might be useful in the real world

When I study, I try to combine different pieces of information from my modules in new ways

When I study, I try to connect what I am learning with my own experiences

\section{LEARNING STYLES}

Below are 12 sentences with a choice of four endings. Rank the endings for each sentence according to how well you think each one fits with how you would go about learning something, from 4 most descriptive of me to 1 least descriptive of me. Try to recall some recent situations where you had to learn something new, perhaps in your job. In ranking the words, use your first impression. There are no right or wrong answers. 


\begin{tabular}{|c|c|c|c|c|}
\hline $\begin{array}{l}\text { 1. When I } \\
\text { learn... }\end{array}$ & $\begin{array}{l}\text {...I like to deal with } \\
\text { my feelings }\end{array}$ & $\begin{array}{l}\text {... l like to watch and } \\
\text { listen }\end{array}$ & $\begin{array}{l}\text {...I like to think about } \\
\text { ideas }\end{array}$ & $\begin{array}{l}\text {...I like to be doing } \\
\text { things. }\end{array}$ \\
\hline $\begin{array}{l}\text { 2. I learn } \\
\text { best } \\
\text { when... }\end{array}$ & $\begin{array}{l}\text {...I trust my hunches } \\
\text { and feelings }\end{array}$ & $\begin{array}{l}\text {...I listen carefully } \\
\text { and watch }\end{array}$ & $\begin{array}{l}\text {...I rely on logical } \\
\text { thinking }\end{array}$ & $\begin{array}{l}\text {...I work hard to get } \\
\text { things done }\end{array}$ \\
\hline $\begin{array}{l}\text { 3. When I } \\
\text { am } \\
\text { learning... }\end{array}$ & $\begin{array}{l}\text {...I have strong } \\
\text { feelings and reactions }\end{array}$ & $\begin{array}{l}\text {...I am quiet and } \\
\text { reserved. }\end{array}$ & $\begin{array}{l}\text {...I tend to reason } \\
\text { things out }\end{array}$ & $\begin{array}{l}\text {...I am responsible } \\
\text { about things }\end{array}$ \\
\hline $\begin{array}{l}\text { 4. I learn } \\
\text { by... }\end{array}$ & ...feeling & ...watching & ...thinking & ...doing \\
\hline $\begin{array}{l}\text { 5. When I } \\
\text { learn... }\end{array}$ & $\begin{array}{l}\text {...I am open to new } \\
\text { experiences }\end{array}$ & $\begin{array}{l}\text {...I look at all sides of } \\
\text { an issue }\end{array}$ & $\begin{array}{l}\text {... I like to analyse } \\
\text { things, break them } \\
\text { into their parts }\end{array}$ & $\begin{array}{l}\text {...I like to try things } \\
\text { out }\end{array}$ \\
\hline $\begin{array}{l}\text { 6. When I } \\
\text { am } \\
\text { learning... }\end{array}$ & $\begin{array}{l}\text {...I am an intuitive } \\
\text { person }\end{array}$ & $\begin{array}{l}\text {...I am an observant } \\
\text { person }\end{array}$ & $\begin{array}{l}\text {...I am a logical } \\
\text { person }\end{array}$ & $\begin{array}{l}\text {...I am an active } \\
\text { person }\end{array}$ \\
\hline $\begin{array}{l}7 . \text { I learn } \\
\text { best from } \\
\cdots\end{array}$ & $\begin{array}{l}\text {...personal } \\
\text { relationships }\end{array}$ & ...observation & ...rational theories & $\begin{array}{l}\text {...a chance to try and } \\
\text { practice }\end{array}$ \\
\hline $\begin{array}{l}\text { 8. When I } \\
\text { learn... }\end{array}$ & $\begin{array}{l}\text {...I feel personally } \\
\text { involved }\end{array}$ & $\begin{array}{l}\text {...I take my time } \\
\text { before acting }\end{array}$ & $\begin{array}{l}\text {...I like ideas and } \\
\text { theories }\end{array}$ & $\begin{array}{l}\text {...I like to see results } \\
\text { from my work }\end{array}$ \\
\hline $\begin{array}{l}9 . \text { I learn } \\
\text { best } \\
\text { when... }\end{array}$ & $\begin{array}{l}\text { II rely on my } \\
\text { feelings }\end{array}$ & $\begin{array}{l}\text {...I rely on my } \\
\text { observations }\end{array}$ & ...I rely on my ideas & $\begin{array}{l}\text {...I can try things out } \\
\text { for myself }\end{array}$ \\
\hline $\begin{array}{l}\text { 10. When I } \\
\text { am } \\
\text { learning... }\end{array}$ & $\begin{array}{l}\text {...I am an accepting } \\
\text { person }\end{array}$ & $\begin{array}{l}\text {...I am a reserved } \\
\text { person }\end{array}$ & $\begin{array}{l}\text {...I am a rational } \\
\text { person }\end{array}$ & $\begin{array}{l}\text {...I am a responsible } \\
\text { person }\end{array}$ \\
\hline $\begin{array}{l}\text { 11. When I } \\
\text { learn ... }\end{array}$ & ...I get involved & ...I like to observe & ...I evaluate things & ...I like to be active \\
\hline $\begin{array}{l}\text { 12. I learn } \\
\text { best } \\
\text { when... }\end{array}$ & $\begin{array}{l}\text {...I am receptive and } \\
\text { open-minded }\end{array}$ & ...I am careful & ...I analyse ideas & ...I am practical \\
\hline Total Score & & & & \\
\hline
\end{tabular}

\section{MOTIVATIONS FOR STUDY}

People choose to study at university for many reasons. Please indicate the extent to which each reason motivates you to study at the University of Exeter. (1 not at all, 5 very much)

To get a good job

To increase my knowledge and understanding

To please my family

To socialise with my friends 
To continue on with my non-academic interests (e.g., playing sport)

To get good grades

OTHER IT SYSTEMS USED IN LEARNING

To what extent do you use the following IT systems/social media platforms while studying at the University of Exeter? ( 1 not at all, 5 all the time)

Facebook

Twitter

Google products (e.g., docs, Scholar) 